\title{
Optical education peculiarity for various specialities in natural sciences
}

Leonid Poperenko

Leonid V. Poperenko, "Optical education peculiarity for various specialities in natural sciences," Proc. SPIE 2525, 1995 International Conference on

Education in Optics, (13 October 1995); doi: 10.1117/12.224073

Event: SPIE's 1995 International Symposium on Optical Science, Engineering, and Instrumentation, 1995, San Diego, CA, United States 
Optical education peculiarity for various specialities in natural sciences

\author{
L. V. Poperenko
}

National Kiev Taras Shevchenko University, 6, ave. Acad. Glushkov, Kiev 252022, Ukraine

National University of Kiev Mohyla Academy, 2, Skovoroda str., Kiev 254070, Ukraine

\begin{abstract}
The issues pertinent to providing optics education as principal base of fundamental higher education in changing the system used to train personnel in the Ukrainian Universities and Technical Institutes are considered.
\end{abstract}

Keywords: optics education, teaching methods, curriculum development, interdisciplinary applications, electronic and optical materials, structures, and devices.

\title{
1. INTRODUCTION
}

Due to the shift of application from defense to commercial markets (communications, medicine, ecology, etc.), there is a need for educators to address how to prepare optics specialists for meeting employers needs in this new market. This is particularly true in Ukraine, where a decision to found an Optics Institute, like Russian State Optics Institute after S. I. Vavilov, has not been made.

Some new specific aspects in optics education exist distinctly in two main National Ukrainian Universities such as Kiev Taras Shevchenko University (KTSU) and the newlyfounded University of "Kiev Mohyla Academy" (UKMA) as independent international University. Both Universities, as symbols of the revival of Ukrainian nationhood, have been taking a leading place in education and infrastructure of science and technology in Ukraine. The Universities actively pursue the participation of industry's scientists to provide a full educational programme at the baccalaureate and post-graduate levels ${ }^{1}$. The core concept of education for the faculty of Natural Sciences of UKMA is the unity of organic and non-organic matter. Naturally this program includes in-depth study of physics, chemistry, biology and in particular ecology. The training of personnel for the latter speciality is very important in Ukraine after the Chornobyl accident. The programs of optics and atomic physics courses are mainly interconnected on problems of the quantum nature of light, lasers and laser's light, holography and nonlinear optics ${ }^{2}$. At the same time the grows of optics applications requires the cross-training of personnel in such fields as medicine and manufacturing.

Similar problems on Education in Optics are also being considered in many other Universities. Many more industries are now using optical technologies, however, many technical staffs have surprisingly limited training in this field. In addition to changing and 
growing role of optics, teaching methods have evolved over the last few years, particularly affected by the advent of multimedia and distance education. Certainly, retraining and continuing education and lifelong learning become real today. Enormous efforts to improve the appropriateness of training have been made in Ukrainian Universities, and there are some improvements in the exchange of information between educators and employers.

It is clear that, in respect to specialization, optical education requires contextual learning approaches, but in any case the interconnection and the exchange of scientific information among optics educators and industry employers should facilitate the evolution of effective education and training in optics.

We identified the following goals:

-to study the experience in optical education at the baccalaureate and post-graduate levels in new specialization's and applications, e.g. interdisciplinary education, ecology, medicine and manufacturing and to obtain definite information about the investigations of the effects of some chemicals on the environment;

-to study methodology principles and curriculum developments in higher education in optics;

-to implement organizational structures for the active participation of students in intensive scientific-research work taking into account transition to Photonics from Laser ElectroOptics and optical education for interdisciplinary applications;

-to prepare on basis of modern practice for optical education new university courses in optics for Ukrainian students on programs of prospective specializatons.

\section{RESULTS}

In order to fulfil our objective it was necessary:

-to use comparative analysis between the undergraduate and Masters Degree programmes in leading Universities over the world and Ukraine, looking for the best possible variant to built an individual programme;

-to attend some lectures and seminars taking into account educational features and pedagogical methods and to learn students` opinions relatively to them;

-to propose and then to carry out some own lectures or/and seminar on selected topics in optics and to discuss the result together with students and corresponding professors;

-to learn a system of credit points for principal subjects in optics and to discuss it together with administration and students;

-to visit some Universities and research centers for study of approaches to scientific research work of undergraduate and graduate students and to discuss together the computer assisted learning, the courses on videotape, using educational equipment, etc., with wellknown academic and industrial leaders in optical science and engineering, who have been chosen for their expertise and teaching ability as course instructors.

The use of a system of credit points for subjects allows students substantial scope and flexibility in planning their course of study within the undergraduate degree framework and is intended to give greater expression to each student's needs. Students are given the 
opportunity of selecting a significant proportion of subjects related to their chosen future major specialization. However, in the first three trimesters, all students undertake instruction in a range of fundamental subjects which provide a broad intellectualhumanitarian foundation relevant not only to their chosen specialization but also for other intellectual endeavours. Thus, every student is required to complete at least one subject from each of the other Faculties (in which the students is not enrolled) ${ }^{2}$.

The proposed method of the considered problem allows:

-to improve our own teaching methods for special courses offered as Optics Chair in KTSU and fundamental courses Optics and Atomic Physics offered as member of the faculty of Natural Sciences in UKMA;

-to direct more applicable scientific research by students in the baccalaureate in both Universities;

-to type the methodical works on some courses in correspondence with results of this task.

The objective of the programme for the undergraduate is to gain a comprehensive and sound knowledge of the disciplines of Physics, Mathematics, Chemistry, Geology, Computer Science, and Biology. in order to enhance their personal intellectual development, students are also required to broaden their studies by completing interdisciplinary courses in the faculties of Humanities and Social Sciences.

Upon successful completion of the four-year full-time programme of studies, students gain a Bachelor of Science Degree with a Major in either Ecology, Physics or Biology. The specific Major will be determined by a number of required specialized course completed for recognition of a Major, and the completion of a minimum of $65 \%$ of all the courses offered in the natural sciences ${ }^{2}$.

All obtained results were reported in scientific and methodical seminars of both Universities and some of them were printed. Special attention was paid for those materials which might be presented as demonstration papers.

Since the conferment of Bachelor of Science Degree or/and Master's Degree at both UKMA and KTSU is an entirely novel affair and the Ukrainian students have not yet gained these degrees, more knowledge of the conclusive studying stage is needed. Unfortunately, lack of adequate research facilities and library resources complicates the search for the main modern points of optics education for interdisciplinary subjects. It would be helpful to research more thoroughly the accomplishment in teaching methodology, particularly in Optical Education for interdisciplinary applications and various specialities in natural sciences.

\section{CONCLUSION}

To accomplish our task in optical education for various specialities it was necessary: -to understand curriculum development in teaching methodology, to establish links betweenaculty and research pursuits for completion phase of the four-year full-time 
programme, and to obtain some data on other programs through library research and use of interviews.

-to carry out some laboratory experiments in a collaborative program linking physicists, chemists, and engineers in research to take into consideration new concepts in the specializations at studying electronic materials, structures, and devices with tailored optical and electronic properties.

\section{ACKNOWLEDGEMENTS}

This work was supported in part by Grant No. APU052084 of International Soros Science Education Programme in Ukraine. Author thanks Assistant Professor of Physics Madeline Msall from Bowdoin College, Brunswick, Maine for discussion.

\section{REFERENCES}

1. I. A. Shaikevich, L. V. Poperenko, P. I. Drozd, "Application of demonstrational devices at studying electromagnetic phenomena," Digest "New technologies in teaching," edited by Ministry of Education of Ukraine, Kiev, N5, pp. 96-103, 1992 (in Russian).

2. L. V. Poperenko, "Abstracts on optics and atomic physics courses programmes" 1994/1995 Calendar of the University of "Kiev Mohyla Academy," Kiev, p.132, 1994. 